\title{
Implementasi Metode Eksperimen Untuk Meningkatkan Hasil Belajar Siswa Pada Materi Cahaya dan Sifat-Sifatnya di Kelas VIII SMP Advent Tondano
}

\author{
Senlly F. Dasmasela ${ }^{*}$, Meike Paat ${ }^{2}$ \\ 1,2 Jurusan Pendidikan IPA, FMIPA, Universitas Negeri Manado \\ *e-mail: florasenllydasmasela@gmail.com
}

\begin{abstract}
Abstrak. Motivasi dan perhatian siswa yang kurang dalam belajar serta guru yang lebih sering menggunakan metode konvensional dalam pembelajaran mengakibatkan rendahnya hasil belajar siswa pada mata pelajaran IPA. Penelitian ini bertujuan untuk meningkatkan hasil belajar siswa pada materi cahaya dan sifat-sifatnya di kelas VIII SMP Advent Tondano melalui implementasi metode eksperimen. Penelitian yang digunakan adalah penelitian tindakan kelas. Subjek penelitian berjumlah 36 siswa. Hasil penelitian menunjukkan bahwa implementasi metode eksperimen dapat meningkatkan hasil belajar siswa pada materi cahaya dan sifat-sifatnya di kelas VIII SMP Advent Tondano, hal ini terlihat dari nilai maksimum hasil belajar siswa di siklus I adalah 85 dan nilai minimum 50 dengan rata-rata nilai 69,44 dan terjadi peningkatan nilai hasil belajar siswa pada siklus II yakni dengan nilai maksimum 95 dan nilai minimum 75 dengan rata-rata nilai 86,53. Demikian juga dengan jumlah ketuntasan hasil belajar siswa kelas VIII SMP Advent Tondano dari 44,44\% di siklus I menjadi 100\% di siklus II. Sehingga disimpulkan bahwa implementasi metode eksperimen dapat meningkatkan hasil belajar siswa pada materi cahaya dan sifat-sifatnya di kelas VIII SMP Advent Tondano.
\end{abstract}

Kata kunci: metode eksperimen, hasil belajar

\begin{abstract}
Lack of motivation and attention from students in learning and teachers who often use conventional methods in learning resulted in low student learning outcomes in science subjects. This study aims to improve student learning outcomes on the material of light and its properties in class VIII SMP Advent Tondano through the implementation of the experimental method. The research used is classroom action research. The research subjects were 36 students. The results showed that the implementation of the experimental method can improve student learning outcomes on light material and its properties in class VIII of SMP Advent Tondano, this can be seen from the maximum value of student learning outcomes in the first cycle is 85 and the minimum value is 50 with an average value of 69.44 and an increase in the value of student learning outcomes in the second cycle with a maximum value of 95 and a minimum value of 75 with an average value of 86.53. Likewise, the number of complete learning outcomes of class VIII students of SMP Advent Tondano from $44.44 \%$ in the first cycle to $100 \%$ in the second cycle. It is concluded that the implementation of the experimental method can improve student learning outcomes on light material and its properties in class VIII of SMP Advent Tondano.
\end{abstract}

Keywords: experimental method, learning outcomes

Diterima 10 Januari 2021 | Disetujui 21 Juni 2021 | Diterbitkan 30 Juni 2021

\section{PENDAHULUAN}

Belajar adalah suatu proses yang ditandai dengan adanya perubahan pada diri seseorang. Perubahan sebagai hasil dari proses belajar dapat diindikasikan dalam berbagai bentuk seperti berubah 
pengetahuan, pemahaman, sikap dan tingkah laku, kecakapan, keterampilan dan kemampuan serta perubahan aspekaspek yang lain yang ada pada individu yang belajar (Trianto dalam Santoso \& Subagyo, 2017).

Belajar juga merupakan suatu upaya untuk menguasai sesuatu yang baru. Konsep ini mengandung dua hal yakni usaha untuk menguasai sesuatu dalam belajar dan sesuatu yang baru dalam hasil yang diperoleh dari aktivitas belajar (Prayitno dalam Fakhrurrazi, 2018). Selain itu, belajar merupakan usaha untuk memperoleh pengetahuan, pemahaman atau penguasaan melalui pengalaman dan studi (Lintong, 2010). Oleh karena itu, belajar dapat diartikan sebagai kegiatan yang menghasilkan perubahan tingkah laku pada diri individu yang sedang belajar, baik potensial maupun aktual. Perubahanperubahan tersebut adalah dalam bentuk kemampuan-kemampuan baru yang dimiliki dalam waktu yang cukup lama, dan perubahan-perubahan itu terjadi karena berbagai usaha yang dilakukan oleh individu yang bersangkutan.

Hasil belajar adalah kemampuan yang dimiliki oleh siswa setelah menerima pengalaman belajar, sebagai suatu proses akibat perubahan setelah mengikuti kegiatan belajar, serta kemampuan-kemampuan yang dimiliki siswa setelah menerima pengalaman belajarnya (Sudjana, 2008). Hasil belajar juga merupakan apa yang dilakukan sebagai hasil yang didapat dari suatu pelajaran (Nasution, 2006). Sehingga, hasil belajar dapat diartikan sebagai sesuatu yang telah dicapai setelah melakukan kegiatan belajar, berhasil tidaknya siswa dalam proses belajar, kemampuan yang dimiliki siswa setelah menerima pengalaman belajar dan sesuatu yang dapat dilihat yakni adanya perubahan yang ada setelah melakukan kegiatan belajar.

Berdasarkan hasil observasi pada mata pelajaran IPA siswa kelas VIII SMP Advent Tondano tahun ajaran 2019-2020 ditemukan beberapa permasalahan yakni kurangnya motivasi dan perhatian siswa dalam belajar sedangkan guru lebih sering menggunakan metode konvensional dalam pembelajaran sehingga siswa lebih memilih aktivitas lain dalam kelas seperti tidak memperhatikan guru pada saat pembelajaran berlangsung, bermain game di dalam kelas bersama teman pada saat guru menjelaskan materi. Kondisi lain dalam proses pembelajaran di kelas adalah guru belum menerapkan metode eksperimen sehingga hal ini berdampak terhadap siswa dalam kegiatan pembelajaran yakni rendahnya hasil belajar siswa pada mata pelajaran IPA. Hal ini terlihat dari nilai hasil evaluasi belajar dengan nilai KKM 75, yang diperoleh dari hasil observasi dan wawancara dengan guru mata pelajaran bahwa sebagian besar siswa tidak tuntas.

Rendahnya hasil belajar siswa tersebut kemungkinan karena kurangnya pemahaman siswa terhadap konsepkonsep dari materi yang diajarkan. Selain itu, guru lebih sering menggunakan metode yang masih bersifat konvensional dalam pembelajaran, sehingga siswa hanya sebatas mendengarkan, memperhatikan materi pelajaran yang diterangkan serta mengerjakan tugas yang diberikan oleh guru. Pembelajaran seperti ini dapat membatasi siswa dalam menuangkan ide, gagasan dan kreatifitas siswa dalam pembelajaran. Keadaan ini menyebabkan siswa lebih cepat bosan dalam mengikuti proses pembelajaran sehingga dapat menyebabkan hasil belajar siswa menjadi rendah.

Untuk mengatasi masalah tersebut diharapkan guru dapat memilih model pembelajaran yang tepat dalam kegiatan pembelajaran yang dapat memotivasi siswa agar lebih aktif dalam kegiatan proses pembelajaran sehingga tujuan pembelajaran dapat tercapai. Untuk dapat mewujudkan hal tersebut, maka diperlukan penerapan metode pembelajaran yang tidak lagi berpusat pada guru, tetapi lebih menjadikan guru sebagai fasilitator. Salah satu metode pembelajaran yang dirasa tepat untuk diterapkan dalam pembelajaran IPA adalah metode eksperimen. 
Metode eksperimen adalah suatu cara mengajar yang memberikan kesempatan pada siswa untuk melakukan suatu percobaan tentang sesuatu hal, mengamati prosesnya serta menuliskan hasil percobaannya, kemudian hasil pengamatan itu disampaikan ke kelas dan dievaluasi oleh guru (Asmani, 2010). Dengan penerapan metode eksperimen ini, diharapkan pembelajaran yang dilaksanakan di dalam kelas akan menjadi lebih bermakna bagi siswa (Shofiah, Bektiarso \& Supriadi, 2017).

Oleh karena itu, peneliti melakukan penelitian yang bertujuan untuk meningkatkan hasil belajar siswa pada materi cahaya dan sifat-sifatnya di kelas VIII SMP Advent Tondano melalui implementasi metode eksperimen.

\section{METODE PENELITIAN}

Penelitian ini dilaksanakan di SMP Advent Tondano tahun pelajaran 2020 pada siswa Kelas VIII. Subjek dalam penelitian ini adalah siswa Kelas VIII SMP Advent Tondano Tahun Pelajaran 2019/2020. Jumlah siswa sebanyak 36 orang yang terdiri dari 19 siswa laki-laki dan 17 siswa perempuan. Objek penelitian ini adalah hasil belajar IPA pada materi cahaya dan sifat-sifatnya dengan menggunakan metode eksperimen.

Penelitian ini merupakan Penelitian Tindakan Kelas (PTK). Penelitian ini dirancang melalui dua siklus yang terdiri atas siklus I dan Siklus II. Pada siklus I terdiri dari persiapan tindakan, implementasi tindakan, observasi dan refleksi siklus I. Apabila pada siklus I belum mencapai kriteria ketuntasan minimal yang ditetapkan maka akan dilanjutkan ke siklus II yang terdiri dari persiapan tindakan, implementasi tindakan, observasi dan refleksi siklus II.

Pada tahap persiapan tindakan, peneliti mempersiapkan segala sesuatu yang diperlukan pada saat penelitian. Adapun hal-hal yang perlu dipersiapkan meliputi Rencana Pelaksanaan Pembelajaran (RPP), materi cahaya dan sifat-sifatnya, menjabarkan materi pembelajaran menjadi sub-sub materi sesuai dengan pedoman kurikulum (K-13 revisi), merumuskan indikator hasil belajar sebagai pembatasan tentang apa yang diharapkan dapat dipahami siswa setelah mengikuti pembelajaran yang didasarkan pada standar kompetensi mata pelajaran, menyiapkan media yang digunakan dalam pembelajaran, melakukan orientasi awal dan pengenalan terhadap rencana penggunaan metode eksperimen. Dalam tahap pelaksanaan siklus I maupun siklus II terdiri dari dua kali pertemuan.

Teknik analisis data penelitian menggunakan analisis perilaku siswa kelas VIII SMP Advent Tondano selama proses pembelajaran berlangsung. Sedangkan analisis kuantitatif digunakan untuk menganalisis hasil belajar materi cahaya dan sifat-sifatnya dengan menggunakan metode eksperimen.

Data yang dianalisis meliputi halhal sebagai berikut: (1) Perubahan yang terjadi pada siswa saat pembelajaran maupun sesudah pembelajaran. Analisis yang digunakan adalah dengan cara menghitung persentase ketuntasan belajar. (2) Peningkatan hasil belajar setiap siklus dengan menghitung persentase ketuntasan hasil belajar siswa dengan rumus $\mathrm{P}=\mathrm{F} / \mathrm{N} \times 100 \%$, dimana $\mathrm{P}$ adalah hasil belajar/ketuntasan belajar siswa secara klasikal, $\mathrm{F}$ adalah jumlah siswa yang belajar tuntas secara individual), dan $\mathrm{N}$ adalah jumlah siswa secara keseluruhan (Arikunto, 2011).

\section{HASIL DAN PEMBAHASAN}

Penelitian ini dilaksanakan untuk mengetahui hasil belajar siswa pada materi cahaya dan sifat-sifatnya melalui penggunaan metode eksperimen. Berdasarkan hasil observasi dan evaluasi dalam proses pembelajaran IPA selama dua siklus atau dua kali tindakan telah berlangsung dengan baik sesuai yang telah direncanakan sebelumnya. Temuan pada saat penelitian menunjukkan bahwa penggunaan metode eksperimen dalam pembelajaran IPA dapat meningkatkan hasil belajar cahaya dan sifat-sifatnya dari siklus I ke siklus II.

Berdasarkan hasil analisis data hasil belajar materi cahaya dan sifat- 
sifatnya dengan menerapkan metode eksperimen pada siklus I dan siklus II, terjadi peningkatan rata-rata hasil belajar dari 69,44 pada siklus I dengan kategori sedang menjadi 86,53 pada siklus II dengan kategori baik. Hasil yang diperoleh ini menunjukkan adanya peningkatan hasil belajar materi cahaya dan sifat-sifatnya karena sudah memenuhi kriteria keberhasilan penelitian dengan persentase ketuntasan klasikal sudah mencapai $100 \%$ dengan rata-rata hasil belajar siswa 86,53.

Persentase ketuntasan siswa secara klasikal yang mencapai 100\% disebabkan karena proses pembelajaran materi cahaya dan sifat-sifatnya pada mata pelajaran IPA menerapkan metode eksperimen sehingga siswa dengan mudah dalam memahami dan mengerti materi yang diajarkan. Dimana dalam penerapan model pembelajaran tersebut dapat meningkatkan pemahaman siswa karena siswa mengalami dan terlibat langsung dalam proses pembelajaran sehingga dapat mempermudah siswa untuk saling bekerja sama, mencerna dan memahami serta mengerti materi cahaya dan sifat-sifatnya pada pelajaran IPA karena metode eksperimen merupakan cara penyajian pelajaran dimana siswa melakukan percobaan dengan mengalami dan membuktikan sendiri sesuatu yang dipelajari.

Hal ini bersesuaian dengan pengertian metode eksperimen yang merupakan suatu cara mengajar yang memberikan kesempatan pada siswa untuk melakukan suatu percobaan tentang sesuatu hal, mengamati prosesnya serta menuliskan hasil percobaannya, kemudian hasil pengamatan itu disampaikan ke kelas dan dievaluasi oleh guru (Asmani, 2010).

Dalam proses pembelajaran, Asmani (2010) mengatakan bahwa metode eksperimen memiliki kelebihan yang sangat besar manfaatnya bagi siswa, antara lain: (1) metode ini dapat membuat anak didik lebih percaya atas kebenaran atau kesimpulan berdasarkan percobaannya sendiri dari pada hanya menerima kata guru atau buku; (2) anak didik dapat mengembangkan sikap untuk mengeksplorasi (menjelajahi) tentang ilmu dan teknologi; (3) dengan metode ini akan terbina manusia yang dapat membawa terobosan-terobosan baru sebagai hasil percobaan yang diharapkan dapat bermanfaat bagi kesejahteraan hidup manusia.

Hasil penelitian ini sejalan dengan beberapa hasil penelitian terdahulu yang sejenis, seperti penelitian yang dilakukan oleh Suarni, Haeruddin \& Dewi (2016) yang mengemukakan bahwa terjadi peningkatan ketuntasan hasil belajar siswa pada pembelajaran siklus I ke siklus II, dimana pembelajaran pada siklus II telah memenuhi indikator keberhasilan, sehingga dikemukakan bahwa perbaikan pembelajaran dengan menggunakan metode eksperimen dapat meningkatkan hasil belajar IPA siswa.

Penelitian lainnya yang relevan yaitu penelitian yang dilakukan oleh Larasati (2015), yang mengemukakan bahwa terdapat perbedaan hasil belajar IPA materi sifat-sifat cahaya siswa antara yang menggunakan metode eksperimen dan yang menggunakan metode demonstrasi, dimana hasil belajar IPA materi sifat-sifat cahaya siswa yang menggunakan metode eksperimen lebih baik dari pada yang menggunakan metode demonstrasi. Sehingga dikemukakan bahwa metode eksperimen efektif terhadap peningkatan hasil belajar siswa pada pembelajaran IPA materi sifat-sifat cahaya.

\section{KESIMPULAN}

Berdasarkan hasil dan pembahasan maka dapat disimpulkan bahwa implementasi metode eksperimen dapat meningkatkan hasil belajar siswa pada materi cahaya dan sifat-sifatnya di kelas VIII SMP Advent Tondano.

\section{DAFTAR PUSTAKA}

Arikunto, S. (2011). Prosedur Penelitian: Suatu Pendekatan Praktik. Jakarta: Rineka cipta.

Asmani, J. M. (2010). Tips Menjadi Guru Inspiratif, Kreatif, dan Inovatif. Jogjakarta: DIVA Press. 
Fakhrurrazi, F. (2018). Hakikat Pembelajaran Yang Efektif. At-Tafkir, 11(1), 85-99.

Larasati, I. (2015). Keefektifan Metode Eksperimen Terhadap Hasil Belajar Sifat-sifat Cahaya Siswa Kelas V SDN 1 Prigi Kabupaten Banjarnegara. Skripsi. Universitas Negeri Semarang.

Lintong, M. M. (2010). Gagasan-Gagasan Pendidikan Kontemporer, Pemberdayaan Mutu Pendidikan di Indonesia. Jakarta: Cahaya Pineleng.

Nasution, S. (2006). Kurikulum dan Pengajaran. Jakarta: PT. Bumi Aksara.

Santoso, H. B., \& Subagyo, S. (2017). Peningkatan Aktifitas Dan Hasil Belajar Dengan Metode Problem Basic Learning (PBL) Pada Mata Pelajaran Tune Up Motor Bensin Siswa Kelas XI Di SMK Insan Cendekia Turi Sleman Tahun Ajaran 2015/2016. Jurnal Taman Vokasi, 5(1), 40-45.

Shofiah, R. I., Bektiarso, S., \& Supriadi, B. (2017). Penerapan Model POE (Predict-Observe-Explain) dengan Metode Eksperimen Terhadap Hasil Belajar IPA dan Retensi Siswa di SMP. Jurnal Pembelajaran Fisika, 6(4), 356363.

Suarni, S., Haeruddin, H., \& Dewi, A. I. (2016). Penerapan Metode Eksperimen pada Materi Sifat Cahaya Pada Mata Pelajaran IPA Kelas V SDN 1 Balukang Untuk Meningkatkan Hasil Belajar Siswa. Jurnal Kreatif Online, 4(1).

Sudjana, N. (2008). Dasar-dasar Proses Belajar Mengajar. Bandung: Sinar Baru Algensindo. 